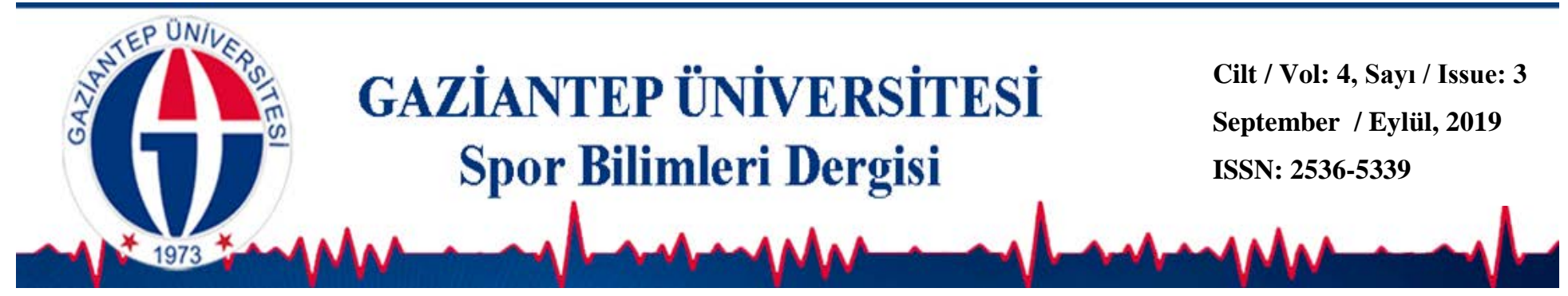

\title{
Gençlik ve Spor İI Müdürlüğü Çalışanlarının Zihinsel Engelli Bireylerin Sportif Etkinliklerine Yönelik Tutum Düzeyinin İncelenmesi (Bingöl İl Örneği)
}

\author{
Atike YILMAZ ${ }^{1 *}$ Hüseyin KIRIMOĞLU $\quad$ Tülin ARSLANBOĞA ${ }^{1}$ (i) \\ Ramazan ARSLANBOĞA ${ }^{1}$
}

${ }^{1}$ Muş Alparslan Üniversitesi, Beden Eğitimi ve Spor Yüksekokulu, MUŞ

DOI: 10.31680/gaunjss.574732

Orijinal Makale / Original Article

Geliş Tarihi / Received: 10.06.2019 Kabul Tarihi / Accepted: 03.09.2019 Yayın Tarihi / Published: 22.09.2019

Öz

Bu çalışmanın amacı, 2018-2019 yılı Gençlik ve spor il müdürlüğü çalışanlarının zihinsel engelli bireylerin sportif etkinliklerine yönelik tutum düzeyinin incelenmesidir. Çalışmada genel tarama yöntemi kullanılmış olup, veri toplama aracı olarak, araştırmacılar tarafından geliştirilen "Kişisel Bilgi Formu” ve İlhan, Esentürk ve Yarımkaya (2016) tarafından geliştirilen "Zihinsel Engelli Bireylerin Sportif Etkinliklerine Yönelik Tutum Ölçeği” kullanılmıştır. Çalışmanın evrenini Bingöl Gençlik ve spor il müdürlüğü çalışanları 110 kişi, örneklem grubunu ise 70 (13 kadın, 57 erkek) oluşturmaktadır. Verilerin analizi SPSS17 programında yapılmıştır. Normallik dağılımı sonucunda verilerin normal dağılmadığı tespit edilmiş olup, değişkenler arasındaki farkı tespit etmek için ikili değişkenlerde Mann Whitney-U, üçlü değişkenler için Kruskal Wallis testi uygulanmıştır. Elde edilen bulgularda, katılımcıların yaş, ailede engelli birey olup olmama durumu, meslek yılı, mezun olunan bölüm, engelli bireyin spor faaliyetine tanık olma değişkenleri açısından anlamlı bir farklılık çıkmamıştır $(p>0,05)$. Ancak, cinsiyet değişkeni açısından zihinsel engelli bireylerin sportif etkinliklerine yönelik tutum ölçeği olumlu tutum alt boyutunda ve spor yapma değişkeni açısından ise, genel tutum ve olumsuzu tutum alt boyutlarında anlamlı farklılık $(p<0,05)$ çıkmıştır. Sonuç olarak katılımcıların yaş, ailede engelli birey olup olmama durumu meslek yılı, mezun olunan bölümün tutum düzeyini etkilemediği, ancak, cinsiyet değişkeni açısından olumlu tutum alt boyutunda kadınlar, spor yapma değişkenini açısından ise genel tutumun spor yapanlar, olumsuz tutum alt boyutunda ise spor yapmayanlar lehine anlamlı çıkmıştır. Bu manada, spor yapmanın katılımcıların tutum düzeyi üzerinde olumlu etkisi olduğunu söyleyebiliriz.

Anahtar Kelimeler: Tutum, zihinsel engelli, spor, Gençlik ve spor il müdürlüğü

\section{Examining the Attitude Levels of the Workers in the Provincial Directorate of Youth and Sports Concerning the Sports Activities of the Mentally Disabled Individuals (Bingöl Province Example)}

\begin{abstract}
The objective of this study is to examine the attitude levels of the workers of the Provincial Directorate of Youth and Sports concerning the sports activities of intellectual disabled individuals. The general survey model was employed in the study. The "Personal Information Form" developed by the researchers and the "Attitude Scale Concerning Sports Activities of intellectual disabled Individuals" developed by İlhan, Esentürk and Yarımkaya (2016) were used as the data collection tools. The universe of the study was comprised of 110 individuals working in the Bingöl Provincial Directorate of Youth and Sports, and the sample group was comprised of 70 (13 female,
\end{abstract}

\footnotetext{
* Sorumlu Yazar: Atike YILMAZ
}

E-mail: atiketan@gmail.com 
Yılmaz A, Kırımoğlu H, Arslanboğa T, Arslanboğa R., (2019). Gençlik ve Spor İl Müdürlüğü Çalışanlarının Zihinsel Engelli Bireylerin Sportif Etkinliklerine Yönelik Tutum Düzeyinin İncelenmesi (Bingöl İl Örneği). Gaziantep Üniversitesi Spor Bilimleri Dergisi, 4(3), 360-372.

57 male) individuals. The analysis of the data was conducted via the SPSS 17 package program. As a conclusion of the normality test, it was determined that the distribution of the data was not normal, the Mann Whitney-U test was used for the paired comparisons and the Kruskal Wallis test was employed for the triple comparisons. The findings demonstrated that there was statistically no significant difference concerning the variables such as age, whether having a disabled family member, working experience, graduated field, and whether the disabled individual witnessed sports activity $(p>0,05)$. However, there was a statistically significant difference $(p<0,05)$ for the gender variable in the positive attitude sub-dimension of the attitude scale concerning the sports activities of the disabled individuals, and similarly, there was a statistically significant difference $(p<0,05)$ for the dealing with sports variable in the general attitude and negative attitude sub-dimensions. As the conclusion, it was determined that the attitude levels of the participants were not influenced from the variables age, whether there is a disabled family member, working experience, and graduated branch; however, it was also determined that there was statistical significance in favor of the females in the positive attitude sub-dimension concerning the gender variable, in favor of the ones dealing with sports in the general attitude concerning the dealing with sports variable, and in favor of the ones not dealing with sports in the negative attitude sub-dimension. In this context, we can state that dealing with sports has a positive influence on the attitude levels of the participants.

Keywords: Attitude, intellectual disabled, sport, Provincial Directorate of Youth and Sports

\section{Giriş}

Gençlik ve spor il müdürlükleri, gençliğin gelişimini desteklemek, farklı genç gruplarının ihtiyaçlarının tespit edilmesi ve kendi potansiyellerini gerçekleştirebilmelerini sağlayacak imkânlar sunmak ve yaşama tam katılımlarını sağlamak ve bu doğrultuda faaliyetler yürütmek ile görevlidir. Bu manada, il müdürlükleri çalışanlarının hizmet sundukları bireylerin gelişim ve ihtiyaçlarının farkında olması doğru hizmet verebilmeleri ve yürütebilmeleri açısından önem arz etmektedir. Spor hizmetlerinde çalışanlar vermiş oldukları hizmetlerde bireylerin istek ve ihtiyaçlarını doğru bir biçimde karşılayabilmeleri için kendilerinin de hem işlerine hem de hizmet verdikleri bireylere karşı olumlu tutuma sahip olması gerekmektedir. Çünkü tutumlar insanların fikirlerini, görüşlerini içeren tepkiler ve davranışlarıdır.

Tutum bir bireyin psikolojik olarak bir nesne ile ilgili düşünce, duygu ve davranışlarını düzenlemesine sebep olan bir eğilim olarak tanımlanmakla beraber çeşitli öğelerden oluşur. Bilişsel öğesinde; bireyin sahip olduğu her türlü bilgi, deneyim, inanç ve düşünceyi içeren sistemli kanıların oluşmasıdır (Ardıç, 2016). Bu manada, gençlik ve spor il müdürlüğü çalışanlarının verilen hizmetlerin içinde yer almaları ve deneyimlemeleri tutumlarının oluşması açısından önemlidir.

Sunulan spor imkânları özel gereksinimli bireylerin spora ulaşması ve engelli sporlarının yaygınlaştırımasının sağlanması amacıyla da çok önemlidir. Sporun engelli bireylerin gelişimsel özellikleri üzerine etkileri bilinmekle birlikte (Yılmaz ve Soyer, 2018; Yılmaz ve ark., 2017; Kırımoğlu ve ark., 2016; Özer ve ark., 2001; Şahin, 2015; Lastuka ve Cottingham, 2016; Lorenzo ve ark., 2019; Sherrill, 2004; Tekkurşun ve ark., 2018; Filazoğlu Çokluk ve ark. 2015; Akın ve Yüksel, 2016; Capio ve ark., 2014; Sperstein ve ark., 2009; Baron ve Faubert 2005; Krebs, 2005; Karakaş 
Yılmaz A, Kırımoğlu H, Arslanboğa T, Arslanboğa R., (2019). Gençlik ve Spor İl Müdürlüğü Çalışanlarının Zihinsel Engelli Bireylerin Sportif Etkinliklerine Yönelik Tutum Düzeyinin İncelenmesi (Bingöl İl Örneği). Gaziantep Üniversitesi Spor Bilimleri Dergisi, 4(3), 360-372.

ve ark. 2016; İlhan, 2010; İlhan, 2008a; İlhan, 2008b; Akın ve Alp, 2019) zihinsel yetersizliği olan bireyler veya bu durumun eşlik ettiği engel türlerinde önemi daha da artmaktadır. Gençlik ve spor il müdürlükleri aracılığı ile sunulan spor hizmetlerinde görev alan spor eğitim uzmanları, antrenörler ve diğer çalışanların zihinsel yetersizliği olan bireylerde sporun etkilerine yönelik olumlu tutuma sahip olması hem bireylerin hem de ailelerin farkındalıklarının artmasını bununla beraber bireylerin sosyal hayata dâhil olma, kendilerini gerçekleştirme, bağımsız yaşam becerilerinin gelişmesi adına önemlidir. Bu doğrultuda çalışmamız Gençlik ve spor il müdürlüğü çalışanlarııın zihinsel engelli bireylerin sportif etkinliklerine yönelik tutum düzeyinin incelenmesi amacıyla gerçekleştirilmiştir. Araştırmada şu sorulara cevap aranmıştır. 1) Gençlik ve spor il müdürlüğü çalışanlarının cinsiyet, yaş, ailede engelli birey olup olmaması, meslek yıll, mezun olunan bölüm, spor yapma durumu ve engelli bireyin spor faaliyetine tanık olup olmadığı değişkenlerine göre zihinsel engelli bireylerin sportif etkinliklerine yönelik tutum düzeylerinde farklılık var mıdır?

\section{Yöntem}

\section{Araştırmanın Modeli}

$\mathrm{Bu}$ araştırmada betimsel araştırma yöntemlerinden biri olan, genel tarama modeli uygulanmıştır. Genel tarama modeli; var olan bir durumu, var olduğu şekli ile tanımlamayı amaçlayan araşııma metodu olarak Karasar (2005) açıklanmaktadır.

\section{Çalışma Grubu}

Bu araştırma Bingöl Gençlik ve spor il müdürlüğü çalışanları 110 kişi, örneklem grubunu ise toplamda 70 (13 kadın, 57 erkek) kişinin gönüllü katıımı ile gerçekleştirilmiştir.

\section{Verilerin Toplanması}

Araştırmada araştırmacılar tarafından geliştirilen "Kişisel Bilgi Formu", ve İlhan, Esentürk ve Yarımkaya (2016) tarafından geliştirilen "Zihinsel Engelli Bireylerin Sportif Etkinliklerine Yönelik Tutum Ölçeği” kullanılmıştır. Katılımcıların zihinsel engelli bireylerin sportif etkinliklerine yönelik tutumları; cinsiyet, yaş, ailede engelli birey olup olmaması, meslek yıll, mezun olunan bölüm, spor yapma urumu ve engelli bireyin spor faaliyetine tanık olup olmadığı açısından değerlendirilmiştir.

Zihinsel Engelli Bireylerin Sportif Etkinliklerine Yönelik Tutum Ölçeği; İlhan, Esentürk ve Yarımkaya (2016) tarafından geliştirilen ölçek 5’li likert tipi bir ölçektir. Ölçek 28 
Yılmaz A, Kırımoğlu H, Arslanboğa T, Arslanboğa R., (2019). Gençlik ve Spor İl Müdürlüğü Çalışanlarının Zihinsel Engelli Bireylerin Sportif Etkinliklerine Yönelik Tutum Düzeyinin İncelenmesi (Bingöl İl Örneği). Gaziantep Üniversitesi Spor Bilimleri Dergisi, 4(3), 360-372.

madde ve Sportif Etkinliklere İlişkin olumlu tutum ve Sportif Etkinliklere İlişkin olumsuz tutum olmak üzere iki alt boyuttan oluşmaktadır. Ölçme aracının Cronbach Alfa güvenirlik katsayısı, ölçeğin genelinde 0.96 olarak bulunmuştur. Ölçeğin "Sportif Etkinliklere Yönelik Olumlu Tutum" (SEYOT) alt boyutunda 0.971, "Sportif Etkinliklere İlişkin Olumsuz Tutum" (SEIOT) alt boyutunda ise, 0.822 tespit edilmiştir.

\section{Verilerin analizi}

Verilerin analizi SPSS17 programında yapılmıştır. Normallik dağılımı sonucunda verilerin normal dağılmadığı tespit edilmiş olup, değişkenler arasındaki farkı tespit etmek için ikili değişkenlerde Mann Whitney-U, üçlü değişkenler için Kruskal Wallis testi uygulanmıştır. Araştırmada anlamlılık düzeyi $p<0,05$ olarak alınmıştır.

\section{Bulgular}

Tablo 1. Katılımcıların değişkenlere göre yüzde ve frekans dağılımları

\begin{tabular}{|c|c|c|c|}
\hline Değişken & & $f$ & $\%$ \\
\hline \multirow[t]{2}{*}{ Yaş } & $18-29$ & 11 & 15,7 \\
\hline & 30- üzeri & 59 & 84,3 \\
\hline \multirow[t]{2}{*}{ Cinsiyet } & Kadın & 13 & 18,6 \\
\hline & Erkek & 57 & 81,4 \\
\hline \multirow{2}{*}{$\begin{array}{l}\text { Ailede engeli birey } \\
\text { olup olmama durumu }\end{array}$} & Evet & 19 & 27,1 \\
\hline & Hayır & 51 & 72,9 \\
\hline \multirow[t]{3}{*}{ Meslek yılı } & $1-5$ & 31 & 44,3 \\
\hline & $6-10$ & 23 & 32,9 \\
\hline & 11- üzeri & 15 & 21,4 \\
\hline \multirow[t]{2}{*}{ Mezuniyet } & BESYO & 19 & 27,1 \\
\hline & Diğer & 51 & 72,9 \\
\hline \multirow[t]{2}{*}{ Spor yapma } & Evet & 44 & 62,9 \\
\hline & Hayır & 26 & 37,1 \\
\hline \multirow{3}{*}{$\begin{array}{l}\text { Engelli bireyin spor } \\
\text { faaliyetine tanık olma }\end{array}$} & Evet & 55 & 78,6 \\
\hline & Hayır & 15 & 21,4 \\
\hline & Genel toplam & 70 & \\
\hline
\end{tabular}

Tablo 1'e katılımcıların, yaş değişkenine göre 18-29 yaş aralığında \%15,7 ile 11 kişi, 30- üzeri \%84,3 ile 59 kişi. Cinsiyet değişkeninde \%18,6 ile 13 kişi kadın, \%81,4 ile 57 erkek, Ailede engeli birey olup olmama durumuna göre \%27,1 ile 19 kişinin evet, \%72,9 ile 51 kişinin hayır dediği. Meslek yılı değişkeni açısından \%44,3 ile 31 kişinin 1-5 yıl, \%32,9 ile 23 kişinin 6-10 yıl ve \%21,4 ile 15 kişinin 11- üzeri meslek yılında olduğu. Mezuniyet durumuna göre, \%27,1 ile BESYO mezunu, \%72,9 ile diğer bölüm mezunu olduğu. Spor yapma değişkenine göre\%62,9 ile 44 kişinin spor yaptığı, \%37,1 ile 26 kişinin spor yapmadığı ve Engelli bireyin spor faaliyetine 
Yılmaz A, Kırımoğlu H, Arslanboğa T, Arslanboğa R., (2019). Gençlik ve Spor İl Müdürlüğü Çalışanlarının Zihinsel Engelli Bireylerin Sportif Etkinliklerine Yönelik Tutum Düzeyinin İncelenmesi (Bingöl İl Örneği). Gaziantep Üniversitesi Spor Bilimleri Dergisi, 4(3), 360-372.

tanık olma değişkenine göre ise, \%78,6 ile 55 kişinin tanık olduğu \%21,4 ile 15 kişinin tanık olmadığı belirlenmiştir.

Tablo 2. Katılımcıların Yaş değişkeni açısından Mann-Whitney U test sonuçları

\begin{tabular}{lllllll}
\hline & \multicolumn{1}{c}{ Yaş } & $\mathbf{n}$ & Sıra ort. & \multicolumn{1}{c}{ Sıra top. } & U & P \\
\hline Genel Tutum & $18-29$ & 11 & 42,32 & 465,50 & 249,500 &, 226 \\
Ort. & $30-$ üzeri & 59 & 34,23 & 2019,50 & &, 162 \\
Olumlu & $18-29$ & 11 & 43,36 & 477,00 & 238,000 & \\
Tutum Ort. & $30-$ üzeri & 59 & 34,03 & 2008,00 & &, 169 \\
Olumsuz & $18-29$ & 11 & 43,23 & 475,50 & 239,500 & \\
Tutum Ort. & $30-$ üzeri & 59 & 34,06 & 2009,50 & & \\
\hline
\end{tabular}

Tablo 2'de katılımcıların yaş değişkenine göre, zihinsel engelli bireylerin sportif etkinliklerine yönelik tutum ölçeği genel tutum puanı, olumlu tutum ve olumsuz tutum alt boyut puanlarına göre anlamlı bir farklııık $(p>0,05)$ tespit edilememiştir.

Tablo 3. Katııımcıların Cinsiyet değişkeni açısından Mann-Whitney U test sonuçları

\begin{tabular}{llllllc}
\hline & Cinsiyet & $\mathbf{n}$ & Sıra ort. & Sıra top. & $\mathbf{U}$ & P \\
\hline Genel Tutum & Kadın & 13 & 46,04 & 598,50 & 233,500 &, $\mathbf{0 3 8}$ \\
Ort. & Erkek & 57 & 33,10 & 1886,50 & & \\
Olumlu & Kadın & 13 & 46,54 & 605,00 & 227,000 &, $\mathbf{0 3 0}$ \\
Tutum Ort. & Erkek & 57 & 32,98 & 1880,00 & & \\
Olumsuz & Kadın & 13 & 43,77 & 569,00 & 263,000 &, 104 \\
Tutum Ort. & Erkek & 57 & 33,61 & 1916,00 & & \\
\hline
\end{tabular}

Tablo 3'de cinsiyet değişkenine göre zihinsel engelli bireylerin sportif etkinliklerine yönelik tutum ölçeği genel tutum, olumlu tutum alt boyut puanlarında anlamlı olduğu tespit edilmiştir $(p<0,05)$. Ancak olumsuz tutum alt boyutunda anlamlı bir farklııı̆a rastlanmamıştır ( $p>0,05)$.

Tablo 4. Katıımcıların ailede engeli birey olup olmama durumu değişkeni açısından Mann-Whitney U test sonuçları

\begin{tabular}{lllllll}
\hline & A.E.B.O. & $\mathbf{n}$ & Sıra ort. & Sıra top. & U & P \\
\hline Genel Tutum & Evet & 19 & 33,32 & 633,00 & 443,000 &, 583 \\
Ort. & Hayır & 51 & 36,31 & 1852,00 & & \\
Olumlu & Evet & 19 & 31,74 & 603,00 & 413,000 &, 345 \\
Tutum Ort. & Hayır & 51 & 36,90 & 1882,00 & & \\
Olumsuz & Evet & 19 & 36,26 & 689,00 & 470,000 &, 848 \\
Tutum Ort. & Hayır & 51 & 35,22 & 1796,00 & & \\
\hline
\end{tabular}

Tablo 4'de katılımcıların ailede engelli birey olma durumu değişkenine göre, zihinsel engelli bireylerin sportif etkinliklerine yönelik tutum ölçeği genel tutum, olumlu tutum ve olumsuz tutum alt boyut puanlarına göre anlamlı farklılık $(p>0,05)$ tespit edilmemiştir. 
Yılmaz A, Kırımoğlu H, Arslanboğa T, Arslanboğa R., (2019). Gençlik ve Spor İl Müdürlüğü Çalışanlarının Zihinsel Engelli Bireylerin Sportif Etkinliklerine Yönelik Tutum Düzeyinin İncelenmesi (Bingöl İl Örneği). Gaziantep Üniversitesi Spor Bilimleri Dergisi, 4(3), 360-372.

Tablo 5. Katılımcıların Meslek yılı değişkeni açısından Kruskal Wallis test sonuçları

\begin{tabular}{lllllll}
\hline & Meslek yılı & $\mathbf{n}$ & Sıra ort. & sd & $\mathbf{X 2}$ & $\mathbf{P}$ \\
\hline Genel tutum & $1-5$ & 31 & 42,23 & 2 & 3,9128 &, $\mathbf{0 4 8}$ \\
& $6-10$ & 24 & 30,25 & & & \\
Olumlu tutum & $11-$ üzeri & 15 & 30,00 & & & \\
& $1-5$ & 31 & 43,69 & 2 & 4,0136 &, $\mathbf{0 1 1 ^ { * }}$ \\
& $6-10$ & 24 & 28,58 & & & \\
Olumsuz tutum & $11-$ üzeri & 15 & 29,63 & & &, 271 \\
& $1-5$ & 31 & 39,71 & 2 & 3,6102 & \\
& $6-10$ & 24 & 33,35 & & & \\
& $11-$ üzeri & 15 & 30,23 & & & \\
\hline
\end{tabular}

Tablo 5'de meslek yılı değişkenine göre zihinsel engelli bireylerin sportif etkinliklerine yönelik tutum ölçeği genel tutum ve olumlu tutum alt boyut puanlarında anlamlı farklılık tespit edilmiştir $(p<0,05)$. Ancak olumsuz tutum alt boyutunda anlamlı farklılığa rastlanmamıştır ( $p>0,05)$.

Tablo 6. Katılımcıların Mezuniyet değişkeni açısından Mann-Whitney U test sonuçları

\begin{tabular}{lllllll}
\hline & Mezuniyet & $\mathbf{n}$ & Sıra ort. & Sıra top. & U & P \\
\hline Genel tutum & BESYO & 19 & 34,97 & 664,50 & 474,500 &, 895 \\
& Diğer & 51 & 35,70 & 1820,50 & & \\
Olumlu & BESYO & 19 & 36,00 & 684,00 & 475,000 &, 900 \\
tutum & Diğer & 51 & 35,31 & 1801,00 & & \\
Olumsuz & BESYO & 19 & 33,16 & 630,00 & 440,000 &, 556 \\
tutum & Diğer & 51 & 36,37 & 1855,00 & & \\
\hline
\end{tabular}

Tablo 6'da katılımcıların mezuniyet değişkenine göre zihinsel engelli bireylerin sportif etkinliklerine yönelik tutum ölçeği genel tutum, olumlu tutum ve olumsuz tutum alt boyut puanlarında anlamlı farklılık $(p>0,05)$ tespit edilememiştir.

Tablo 7. Katılımcıların spor yapma değişkeni açısından Mann-Whitney $U$ test sonuçları

\begin{tabular}{lllllll}
\hline & $\begin{array}{c}\text { Spor } \\
\text { yapma }\end{array}$ & $\mathbf{n}$ & Sıra ort. & Sıra top. & U & P \\
\hline Genel tutum & Evet & 44 & 35,33 & 1554,50 & 564,500 &, 927 \\
& Hayır & 26 & 35,79 & 930,50 & & \\
Olumlu & Evet & 44 & 37,59 & 1654,00 & 480,000 &, 263 \\
tutum & Hayır & 26 & 31,96 & 831,00 & & \\
Olumsuz & Evet & 44 & 31,52 & 1387,00 & 397,000 &, $0^{*}$ \\
tutum & Hayır & 26 & 42,23 & 1098,00 & & \\
\hline
\end{tabular}

Tablo 7'de katılımcıların spor yapma değişkenine göre zihinsel engelli bireylerin sportif etkinliklerine yönelik tutum ölçeği genel tutum, olumlu tutum alt 
Yılmaz A, Kırımoğlu H, Arslanboğa T, Arslanboğa R., (2019). Gençlik ve Spor İl Müdürlüğü Çalışanlarının Zihinsel Engelli Bireylerin Sportif Etkinliklerine Yönelik Tutum Düzeyinin İncelenmesi (Bingöl İl Örneği). Gaziantep Üniversitesi Spor Bilimleri Dergisi, 4(3), 360-372.

boyutlarına göre anlamlı bir farklılık $(p>0,05)$ tespit edilmiştir. Ancak olumsuz tutum alt boyutunda anlamlı farklılığa rastlanmamıştır $(p<0,05)$.

Tablo 8. Katılımcıların engelli bireyin spor faaliyetine tanık olma değişkeni açısından Mann-Whitney U test sonuçları

\begin{tabular}{lllllll}
\hline & S.F.T.O. & $\mathbf{n}$ & Sıra ort. & Sıra top. & U & P \\
\hline Genel tutum & Evet & 55 & 36,33 & 1998,00 & 367,000 &, 514 \\
& Hayır & 15 & 32,47 & 487,00 & & \\
Olumlu & Evet & 55 & 36,40 & 2002,00 & 363,000 &, 478 \\
tutum & Hayır & 15 & 32,20 & 483,00 & & \\
Olumsuz & Evet & 55 & 35,08 & 1929,50 & 389,500 &, 742 \\
tutum & Hayır & 15 & 37,03 & 555,50 & & \\
\hline
\end{tabular}

Tablo 8'de katılımcıların engelli bireyin spor faaliyetine tanık olma değişkenine göre zihinsel engelli bireylerin sportif etkinliklerine yönelik tutum ölçeği genel tutum, olumlu tutum ve olumsuz tutum alt boyut puanlarına göre anlamlı bir farklılık $(p>0,05)$ tespit edilememiştir.

\section{Tartışma ve Sonuç}

Ülkelerin kalkınmışlık düzeyleri, engelli bireylerin yaşam kalitesi ve verilen hizmetlerle de ilişkilidir (Çevik ve Kabasakal, 2013). Günümüzde engelli bireylerin spor ile uğraşması ve spor hizmetlerinden faydalanması yaygınlaşmaktadır. Bu manada, engelli bireylere spor hizmeti veren kuruluşların faaliyetleri ve bu yöndeki tutumlarının önemli olduğu söylenebilir.

Bingöl ili, Gençlik ve spor il müdürlüğü çalışanlarının zihinsel engelli bireylerin sportif etkinliklerine yönelik tutum düzeyinin belirlenmesi amacıyla gerçekleştirilen çalışmadan elde edilen bulgularda, katılımcıların yaş, ailede engeli birey olup olmama durumu, meslek yılı, mezun olunan bölüm, engelli bireyin spor faaliyetine tanık olma değişkenleri açısından anlamlı bir farklılık çıkmamıştır ( $p>0,05)$. Ancak, cinsiyet değişkeni açısından zihinsel engelli bireylerin sportif etkinliklerine yönelik tutum ölçeği olumlu tutum alt boyutunda ve spor yapma değişkeni açısından ise, genel tutum ve olumsuzu tutum alt boyutlarında anlamlı farklılık $(p<0,05)$ çıkmıştır. Katılımcıların spor yapma değişkenine göre zihinsel engelli bireylerin sportif etkinliklerine yönelik tutum ölçeği genel tutum, olumlu tutum alt boyutlarına göre anlamlı bir farklılık tespit edilmiştir. Ancak olumsuz tutum alt boyutunda anlamlı farklılığa rastlanmamıştır. Elde edilen sonuçlar tek tek irdelenecektir. 
Yılmaz A, Kırımoğlu H, Arslanboğa T, Arslanboğa R., (2019). Gençlik ve Spor İl Müdürlüğü Çalışanlarının Zihinsel Engelli Bireylerin Sportif Etkinliklerine Yönelik Tutum Düzeyinin İncelenmesi (Bingöl İl Örneği). Gaziantep Üniversitesi Spor Bilimleri Dergisi, 4(3), 360-372.

Katılımcıların yaş değişkeni açısından zihinsel engelli bireylerin sportif etkinliklerine yönelik tutum düzeylerinde genel tutum, olumlu tutum ve olumsuz tutum alt boyutlarında anlamlı farklılık çıkmamıştır. Bu nedenle Gençlik ve spor il müdürlüğü çalışanlarının yaş değişkenine göre zihinsel engelli bireylerin sportif etkinliklerine yönelik tutumlarını etkilemediğini söyleyebiliriz. Zihinsel engelli bireylerin sportif etkinliklerine yönelik tutum çalışmaları da (Öztürk ve Abakay, 2014; Yaralı, 2015) çalışmamızı destekler niteliktedir. Cinsiyet değişkenine göre zihinsel engelli bireylerin sportif etkinliklerine yönelik tutum ölçeği genel tutum, olumlu tutum alt boyutunda anlamlı farklılık tespit edilmiştir. Ancak olumsuz tutum alt boyutunda anlamlı bir farklıı̆ğa rastlanmamıştır. Bu farklılığın ortalamalar düzeyinde kadın katılımcılar lehine oluğu belirlenmiştir. Bu manada kadın katılımcıların erkeklere göre daha yüksek düzeyde tutuma sahip olduğunu söyleyebiliriz. Yapılan çalışmalarda da (Downs ve Williams, 1994; Lyons ve Hayes, 1993; Tervo ve ark., 2002; Yıldırım ve ark., 2010) destekler nitelikte iken (Şahin ve Bekir, 2016; Açak ve ark., 2016; Kırımoğlu ve ark., 2017) yapmış oldukları çalışmalarda cinsiyetin tutum üzerine etkisi olmadığını belirtmişlerdir.

Ailede engeli birey olup olmama durumu değişkeni açısından da zihinsel engelli bireylerin sportif etkinliklerine yönelik tutum düzeylerinde genel tutum, olumlu tutum ve olumsuz tutum alt boyutlarında anlamlı farklılık çıkmamıştır. Yapılan çalışmalar (Kırımoğlu ve ark., 2017; Şahin ve Bekir, 2016; Çolak ve Çetin, 2014) çalışmamızla paralellik göstermekle birlikte, toplumdaki engelli farkındalığının artmasının sonucu etkilediğini söyleyebiliriz. Engelli bireyin spor faaliyetine tanık olma değişkenleri açısından tutum düzeyleri incelendiğinde anlamlı bir farklılık çıkmamıştır Öztürk ve Abakay, 2014 ve Kırımoğlu ve ark., 2017; yaptıkları çalışmada çalışmamızı destekler niteliktedir. Ancak, Yılmaz ve ark., (2015) yapmış oldukları çalışmada engelli bireylerin spor faaliyetlerine tanık olmanın farkındalığı arttırdığı arttırdığını belirtmişlerdir. Bunun yanında, yapılan çalışmalarda engellilere yönelik verilen eğitimlerin tutumu olumlu yönde etkilediği (Hwang ve Evans, 2011; Şahin ve Güldenoğlu, 2013; Melekoğlu, 2013) belirtilmiştir.

Katılımcıların meslek yılı açısından zihinsel engelli bireylerin sportif etkinliklerine yönelik tutum düzeylerinde anlamlı bir farklılık çıkmamıştır. Yapılan çalışmalarda da ( Diken ve Sucuoğlu, 1999; Eratay ve Çetin, 2013) meslek yılının engellilere yönelik tutumu değiştirmediğini belirtmişlerdir. Mezun olunan bölüm 
Yılmaz A, Kırımoğlu H, Arslanboğa T, Arslanboğa R., (2019). Gençlik ve Spor İl Müdürlüğü Çalışanlarının Zihinsel Engelli Bireylerin Sportif Etkinliklerine Yönelik Tutum Düzeyinin İncelenmesi (Bingöl İl Örneği). Gaziantep Üniversitesi Spor Bilimleri Dergisi, 4(3), 360-372.

değişkeni açısından araştırmamızda ki BESYO ve Diğer bölüm mezunları arasına zihinsel engelli bireylerin sportif etkinliklerine yönelik tutum düzeylerinde anlamlı bir farklılık çıkmamıştır. Yaralı (2015) bölüm değişkenine göre öğretmen adaylarının engelli bireylere yönelik tutumlarını incelediği çalışması da araştırmamızla paralellik göstermektedir. Aksine bazı çalışmalarda ( Kırımoğlu ve ark., 2017; Şahin ve Bekir, 2016) bölüm değişkeninin tutum düzeylerini etkilediği belirtilmiştir. Bu manada gençlik ve spor il müdürlüğü çalışanlarının engellilere yönelik yapılan faaliyetlerde görev almaları ve deneyimlemeleri çalışanların mezun olunana bölüm farklılığını ortadan kaldırdığını söyleyebiliriz. Katılımcıların spor yapma değişkenine göre araştırmamızda zihinsel engelli bireylerin sportif etkinliklerine yönelik tutum ölçeği genel tutum, olumlu tutum alt boyutlarına göre anlamlı bir farklılık tespit edilmiştir. Ancak olumsuz tutum alt boyutunda anlamlı farklılığa rastlanmamıştır. Bu manada spor yapmanın bireylere kazandırdığı olumlu etkilerini deneyimlemeleri, katılımcıların zihinsel engelli bireylerin sportif etkinliklerine yönelik tutumlarına da pozitif yönde etki ettiğini söyleyebiliriz.

Sonuç olarak; gençlik ve spor il müdürlüğü çalışanlarının yaş, ailede engelli birey olup olmama durumu meslek yılı, mezun olunan bölümün tutum düzeyini etkilemediği, ancak, cinsiyet değişkeni açısından olumlu tutum alt boyutunda kadınlar lehine, spor yapma değişkenini açısından ise genel tutumun spor yapanlar, olumsuz tutum alt boyutunda ise spor yapmayanlar lehine anlamlı çıkmıştır. Bu manada, spor yapmanın Bingöl Gençlik ve spor il müdürlüğü çalışanlarının tutum düzeyi üzerinde olumlu etkisi olduğunu söyleyebiliriz.

\section{Kaynaklar}

Açak, M., Karakaya, Y.E., Tan, Ç. ve Coşkuner, Z. (2016). Investıgatıon Of The Attıtudes Of Students From Exercise And Sports Education For Individuals With Disabılitıes Department Toward Indıviduals With Disabılıtıes, International Periodical for the Languages, Literature and History of Turkish or Turkic, 11(19), 1-8.

Akın, S., ve Alp, H. (2019). Effect of Adapted Game-Aided Physical Education Program on the Motor Skills of Children with Autism Spectrum Disorders: Longitudinal Case Study, Journal of Curriculum and Teaching, 8(3),63-72. 
Yılmaz A, Kırımoğlu H, Arslanboğa T, Arslanboğa R., (2019). Gençlik ve Spor İl Müdürlüğü Çalışanlarının Zihinsel Engelli Bireylerin Sportif Etkinliklerine Yönelik Tutum Düzeyinin İncelenmesi (Bingöl İl Örneği). Gaziantep Üniversitesi Spor Bilimleri Dergisi, 4(3), 360-372.

Akın, S., ve Yüksel, O. (2016). Spor Yapan ve Yapmayan Zihinsel Engelli Çocukların Dinamik Denge Düzeylerinin Değerlendirilmesi, Sportif Bakış: Spor ve Eğitim Bilimleri Dergisi, 3 (1), 33-40.

Ardıç, A. (2016). Özel gereksinimli bireylere yönelik tutumlar, Veysel Aksoy (Ed.) Özel Eğitim (s.237-266). Ankara: Pegem Akademi.

Baron, L. J. ve Faubertb, C. (2005). The role of Tai Chi Chuan in reducing state anxiety and enhancing mood of children with special needs, Journal of Bodywork and Movement Therapies. 9(2),120-133.

Capio, C. M., Sit, C.H.P., Eguia, K.F., Abernethy. B. ve Masters, R.S.W. (2014). Fundamental movement skills training to promote physical activity in children with and without disability: A pilot study. Journal of Sport and Health Science, 4 (2015), 235-243.

Çevik, O., ve Kabasakal, K. (2013). Spor etkinliklerinin, engelli bireylerin toplumsal uyumuna ve sporla sosyalleşmelerine etkisinin incelenmesi. International Journal of Social and Economic Sciences (IJSES), 3(2), 74-83.

Çolak, M., ve Çetin, C. (2014). Öğretmenlerin engelliliğe yönelik tutumları üzerine bir araştırma. Dokuz Eylül Üniversitesi İktisadi ve İdari Bilimler Fakültesi Dergisi, 29(1), 191-211.

Diken, I. H., ve Sucuoğlu, B. (1999). Sınıfında zihin engelli çocuk bulunan ve bulunmayan sınıf öğretmenlerinin zihin engelli çocukların kaynaştııılmasına yönelik tutumlarının karşılaştıııması. Ankara Üniversitesi Eğitim Bilimleri Fakültesi Özel Eğitim Dergisi, 2(03).

Downs, P., ve Williams, T. (1994). Student attitudes toward integration of people with disabilities in activity settings: a European comparison. Adapted Physical Activity Quarterly, 11:32-43.

Eratay, E., ve Çetin, M. E. (2013). Bolu Illindeki İşverenlerin Engelli Çalışanlara Yönelik Tutumları. Kastamonu Eğitim Dergisi, 21(4), 1681-1694.

Filazoğlu-Cokluk, Kırımoğlu, H., G., Oz, A.Ş. ve İlhan, E.L. (2015) The Effects of Physical Education and Sports on the Self-Concept of the Children with Mild Mental Disabilities. International Journal of Science Culture and Sport (IntJSCS). Special Issue on the Proceedings of the 4th ISCS Conference PART A. Special Issue 3:55-72. 
Yılmaz A, Kırımoğlu H, Arslanboğa T, Arslanboğa R., (2019). Gençlik ve Spor İl Müdürlüğü Çalışanlarının Zihinsel Engelli Bireylerin Sportif Etkinliklerine Yönelik Tutum Düzeyinin İncelenmesi (Bingöl İl Örneği). Gaziantep Üniversitesi Spor Bilimleri Dergisi, 4(3), 360-372.

İlhan, E. L. (2010). Hareketsiz Yaşamlar Kültürü ve Beraberinde Getirdikleri. Milli Prodüktivite Merkezi Verimlilik Dergisi, 3,195-210

İlhan, E. L., Esentürk, O. K., ve Yarımkaya, E. (2016). Zihinsel engelli bireylerin sportif etkinliklerine yönelik tutum ölçeği (zebseytö): Geçerlik ve güvenirlik çalışması. Journal of Human Sciences, 13(1), 1141-1160.

İlhan, L. (2008a). Eğitilebilir zihinsel engelli çocuklarda beden eğitimi ve sporun sosyalleşme düzeylerine etkisi, Kastamonu Eğitim Fakültesi Dergisi, 16(1), 315-324.

İlhan, L. (2008b). Zihinsel engelli çocuklar için beden eğitimi ve sporun genel gelişim süreçleri açısından önemi. Çağdaş Eğitim Dergisi, 33(350), 17-24.

Karakaş, G.,Yılmaz, A. ve Kaya, B. H. (2016) Teachers Comments By 5-6 Age Children With Autism Spectrum Disorders And Behavior Ofthe Effect Of Social Skills Level Sports. Niğde University Journal Of Physical Education And Sport Sciences, 10(2), 280-294.

Karasar, N. (2005). Bilimsel Araştırma Yöntemleri, Nobel Yayınları. Ankara.

Kırımoğlu H., Filizoğlu-Çokluk G., İlhan E. L. ve Öz, A. Ş. (2016). The effect of physical education and sports program on the positive growth and coping strategies of the adolescent with mental retardation. SHS Web of Conferences, 26(4), 1086-1092. doi: 10.1051/shsconf/20162601086.

Kırımoğlu, H., Dallı, M., Yılmaz, A., ve Say, M. (2017). Öğretmen adaylarının zihinsel engelli bireylerin sportif etkinliklerine yönelik tutum düzeylerinin incelenmesi (Muğla Sıtkı Koçman Üniversitesi örneği). Journal of Human Sciences, 14(4), 3116-3125. doi:10.14687/jhs.v14i4.4670.

Krebs, P. (2005). Adapted Physical Education and Sport. Fourth Edition. (Editor:Winnick, J.). Chapter 11. Intellectual Disabilities. Human Kinetics. ISBN: 0-7360-5216-X. State University. New York. ss.140.

Lastuka, A., ve Cottingham, M. (2016). The effect of adaptive sports on employment among people with disabilities. Disability and rehabilitation, 38(8), 742-748.

Lorenzo, T., McKinney, V., Bam, A., Sigenu, V., ve Sompeta, S. (2019). Mapping participation of disabled youth in sport and other free-time activities to facilitate their livelihoods development. British Journal of Occupational Therapy, 82(2), 80-89. 
Yılmaz A, Kırımoğlu H, Arslanboğa T, Arslanboğa R., (2019). Gençlik ve Spor İl Müdürlüğü Çalışanlarının Zihinsel Engelli Bireylerin Sportif Etkinliklerine Yönelik Tutum Düzeyinin İncelenmesi (Bingöl İl Örneği). Gaziantep Üniversitesi Spor Bilimleri Dergisi, 4(3), 360-372.

Lyons M., ve Hayes R. (1993). Student perceptions of persons with psychiatric and other disorders. American Journal of Occupational Therapy, 47:541-548.

Melekoğlu, M.A. (2013). Özel Gereksinimli Öğrencilerle Yürütülen Etkileşim Projesinin Genel Eğitim Öğretmenlerinin Kaynaştırma Uygulamalarına Yönelik Olumlu Tutum ve Farkındalık Geliştirmeleri Üzerindeki Etkilerinin Belirlenmesi. Kuram ve Uygulamada Eğitim Bilimleri, 13(2), 1053-1077.

Özer, D., Süngü, B., ve Şılak, B. (2001). Physical education and sports for people with disabilities. Researcher, III. Symposium on New and Creative Approaches in Physical Education and Sport Education. 35.

Öztürk, H., ve Abakay, U. (2014). Research of attitudes of the students studying in schools of physical education and sport toward disabled kids, Turkish Journal of Sport and Exercise, 16(3), 66-68.

Sherrill, C. (2004). Adapted physical activity, recreation and sport. New York: McGraw Hill.

Sperstein, G. N., Glick, G. C., ve Parker, R. C. (2009). Social inclusion of children with intellectual disabilities in a recreational setting. Intellectual and Developmental Disabilities, 47(2), 97-107. doi: 10.1352/1934-9556-47.2.97.

Şahin, A. (2015). Social Progress Inadequacies In The Handicapped: Benefits Of Sport In Socialising Process. Journal of International Multidisciplinary Academic Researches, 2(3), 20-28.

Şahin, H., ve Bekir, H. (2016). Üniversite Öğrencilerinin Engellilere Yönelik Tutumlarının Belirlenmesi, Türkiye Sosyal Araştırmalar Dergisi, 3:743-766.

Şahin F., ve Güldenoğlu, B. (2013). Engelliler Konusunda Verilen Eğitim Programının Engellilere Yönelik Tutumlar Üzerindeki Etkisi. Amasya Üniversitesi, Eğitim Fakültesi Dergisi. 2(1), 214-239.

Tekkurşun-Demir, G., İlhan, L. E., Esentürk,. O., ve Kan, A. (2018). Engelli Bireylerde Spora Katılım Motivasyonu Ölçeği (Eskmö): Geçerlik Ve Güvenirlik Çalışması, Spormetre, 16 (1), 91-102: 091-102 dol: 10.1501/Sporm_0000000347.

Tervo, R. C., Azuma, S., Palmer, G. ve Redinius P. (2002). Medical students' attitudes toward persons with disability: a comparative study. Archives of Physical Medicine and Rehabilitation.83: 1537-42. 
Yılmaz A, Kırımoğlu H, Arslanboğa T, Arslanboğa R., (2019). Gençlik ve Spor İl Müdürlüğü Çalışanlarının Zihinsel Engelli Bireylerin Sportif Etkinliklerine Yönelik Tutum Düzeyinin İncelenmesi (Bingöl İl Örneği). Gaziantep Üniversitesi Spor Bilimleri Dergisi, 4(3), 360-372.

Yaralı, D. (2015). Öğretmen adaylarının özel gereksinimli bireylere yönelik tutumlarının bazı değişkenler açısından incelenmesi. Journal of Education Faculty, 17(2), 431-455.

Yıldırım, S. H., Bektaş, M., ve Altıparmak, S. (2010). Hemşirelik Öğrencilerinin Engellilere Yönelik Tutumlarının Belirlenmesi. Yeni Tıp Dergisi.27: 80-83.

Yılmaz, A., ve Soyer, F. (2018). Effect of Physical Education and Play Applications on School Social Behaviors of Mild-Level Intellectually Disabled Children. Education Sciences, 8(2), 89.

Yılmaz, A., Karakaş, G., Baba-Kaya, H., ve Kaçay, Z. (2017). The effects of sportive exercises on physical fitness of children with specific learning disability. Acta Kinesiologica, 11(1), 88-93.

Yılmaz, A., Soyer, F., Beyleroğlu, M., İlhan, E. L. ve Kırımoğlu, H. (2015). Beden Eğitimi ve Spor Öğretmen Adaylarının Zihinsel Yetersizliğe Sahip Bireylerde Sporun Etkilerine Yönelik Farkındalık Düzeylerinin İncelenmesi, 1. Uluslararası Spor Eğitim ve Sağlık Bilimleri Kongresi, 1-3 Mayıs 2015, Sakarya.

Hwang, Y. S., ve Evans, D. (2011). Attitudes towards inclusion: Gaps between belief and practice. International Journal of Special Education, 26(1), 136-146. 